\title{
Morphological Developments of Orchis purpurea Huds. Salep Orchids
}

\author{
Omer Caliskan ${ }^{1}$ \\ https://orcid.org/0000-0003-2235-3184 \\ Dursun Kurt ${ }^{1 *}$ \\ https://orcid.org/0000-0001-6697-3954

\section{Mehmet Serhat Odabas ${ }^{2}$ \\ https://orcid.org/0000-0002-1863-7566}

${ }^{1}$ University of Ondokuz Mayis, Bafra Vocational School, Department of Plant and Animal Production, Samsun, Turkey; 2University of Ondokuz Mayis, Faculty of Agriculture, Department of Field Crops, Samsun, Turkey.

Received: 2019.12.23; Accepted: 2020.03.30.

*Correspondence: dursun.kurt@omu.edu.tr; Tel.: +90-362-5426762

\section{HIGHLIGHTS}

- Findings are first data for species.

- Most important contribute to harvest characteristics is made by tuber length.

- Leaf area prediction modeling performed highly accurate results.

- Main tuber completes its life by producing larger new tuber.

\begin{abstract}
This article aims to monitor the development of Orchis purpurea Huds., salep orchids, of different sizes over a period of two years, and to investigate the relationship between the parameters studied. In the first step, the measurements taken at the time of planting and harvesting of tubers divided into eight different groups according to their size were subjected to variance and Duncan's test. In the second step, the relationship between the parameters was investigated by ignoring seedling groups. The relationship between the two variables was determined by correlation analysis. The significance of the relationships between planting and harvest data sets, and variable contributions were determined by canonical correlation analysis. Finally, leaf area prediction modeling was performed by applying multiple regression analysis. In variance analysis all parameters were significant. The canonical correlation between the first pair of canonical variables was $0.988(p<0.01)$. The data obtained from the tubers made the greatest contribution to the explanatory power of the canonical variables. The leaf area model was formulized as $L A\left(\mathrm{~mm}^{2}\right)=-1237.0204$ $+57.7912 \times \mathrm{LW}+16.6211 \times \mathrm{LL}$ where LA is leaf area, LW is leaf width, LL is leaf length and $a, b$, and $c$ are coefficients.
\end{abstract}

Keywords: canonical correlation; morphology; modeling; multivariate; terrestrial. 


\section{INTRODUCTION}

Orchidaceae is the second largest family of flowering plants with its 30 thousand species. This number is increasing every day with newly found and hybrid species [1-4]. According to Govaerts and coauthors [5], the number of species included in the family is 28.484 , and it is distributed almost globally. Arditti [6] reported that around $70 \%$ of orchids in the world grow in epiphytic and/or lithophytic substrates, $25 \%$ in terrestrial and $5 \%$ in mixed substrates (lithophytic, epiphytic and terrestrial) [7].

Within the family, species that are grouped as terrestrial orchids and produce tubers under the ground are known as salep orchids. At least 35 species of orchids are used to make salep, including species from the genera Anacamptis, Dactylorhiza, Himantoglossum, Ophrys, Orchis, Serapias and Steveniella [7-12]. Tubers of orchis have been used as medicinal plants for centuries. Medicinal orchids are widely traded worldwide for use in various traditional medicines and health supplements, including Europe [13]. It is widely used to cure various diseases including dysentery, diarrhea, chronic fever, cough, stomachache, wounds, cuts, burns, fractures, and general weakness [14-17]. In Turkey, salep derived from the plants are used in the food sector including primarily the ice-cream industry. For this purpose, millions of salep plants are disrooted every year to produce salep [18].

The common characteristic of all orchids is that they all have very small, microscopic seeds. The most important thing that distinguishes the family of orchids from other seed plants is the absence of endosperm in orchid seeds. It has the smallest known seeds in the plant kingdom [19-21]. Another noteworthy issue in the seed structure is that the parts that will form the plant parts such as root, stem, shoot after germination are not shaped. This condition is called morphological dormancy. In short, these are incomplete seeds with primitive embryos and without an endosperm [22-25]. A mature salep orchid can produce at least 8-10 seed capsules [26] and tens of thousands of seeds in each orchid capsule [7]. During germination, the seeds cannot grow without support from a different living organism. In nature, they rely on a suitable symbiotic association with mycorrhizal fungi [20, 27-30]. For this reason, out of the large number of seeds that the orchids scatter around, perhaps one millionth of them have a chance to germinate [31].

Salep orchids are among the species that cannot be produced under normal conditions due to this deficiency in their seeds. Therefore, its collection and trade are prohibited worldwide. Salep orchids are included in the appendix-II of the CITES (Convention on International Trade in Endangered Species of Wild Fauna and Flora) signed by 183 countries. Trade in all species of the Orchidaceae is controlled by CITES [32]. By the end of 2017, the IUCN Global Red List included assessments for 948 orchid species, of which $56.5 \%$ are reported to be, threatened $[7,33]$. However, the number of orchid species in nature is rapidly decreasing due to the difficulty of germination of their seeds and the illegal collection. In addition, migration to climatologically suitable regions with climate change is accelerating the extinction of habitats and species $[7,34]$.

The development of seeds that can germinate in salep orchids is also very slow and takes many years. In the first year, one or two small leaves are formed from germinated seed, and plantlets that produce a tuber lighter than one gram are formed. The tiny tuber formed in the first year produces a larger tuber than itself in the next year. This process continues in the following years. The tuber formed in each new vegetation year is larger than its parent [35-37]. However, there are few sources about the development and growth status of tubers planted in salep orchids. In this study, a species belonging to the genus Orchis, which has a wide spreading area in temperate zone, was selected as plant material to contribute to its development and growth status.

In scientific studies, data relating to a large number of related (dependent) or unrelated (independent) properties called variables are obtained from the samples examined. The fact that use of univariate statistical approaches is much preferred by researchers, especially because their results are easily interpretable in data sets whose effects are interrelated and variables are related in such a way often prevents the uncovering of hidden information between variables [38]. Therefore, multivariate analysis techniques have come to the forefront in determining the relationships between two or more sets of variables in terms of research being healthy and reliable [39]. Although there is no obligation in this method, one of the variable sets can be considered as dependent and the other as independent variable set. In analysis, new variables are obtained from the linear compositions of the variables contained in each set. These new variables are called canonical variables and the correlation between these new variables is intended to be maximum [40,41]. Canonical correlation analysis examines the relationship between two sets of random variables consisting of a large number of variables [42]. In plant and animal breeding studies, it is necessary to carry out such studies in order to reveal the relationship structure between the early identified characteristics and the late identified 
and economically important characteristics without disturbing the integrity between the characteristics, and to be able to direct selection studies accordingly [40].

Mathematical models obtained by multiple regression analysis are used to determine the relationship between two or more variables with cause-effect relationship and make predictions using this relationship [43]. In these mathematical models, variables must be divided into two groups as dependent variables and independent variables. A dependent variable is a variable that is tried to be explained by independent variables. These models are used for making predictions in various disciplines such as medicine, engineering, agriculture, economics, business, etc. [44].

Among salep orchids, the genus Orchis has a high diversity with more than one hundred species [45, 46]. One of the most common species of the genus orchis is Orchis purpurea (Huds). This species is widely spread to Central Asia, Europe, Southern part of UK Islands, North Africa and the Caucasus [47-51]. It is among the most common species in Turkey, especially in coastal regions [35].

There are no data on Orchis purpurea (Huds) and only a few studies on the development of the tuber planted, new tuber yield and differences in vegetative characteristics in orchid species. The recent studies identified are limited to the studies of the same author team on Dactylorhiza romana (Sebast.) Soo. [36] species and Ophrys sphegodes subsp. mammosa (Desf.) Soo ex E. Nelson. [37] species, and the one-year study on Ophrys lutea, Serapias vomeracea, Ophrys mammosa, Ophrys umbilicata, and Orchis sancta species [52]. Previous studies, however, do not go beyond morphological identification in general. In this study, the development performance of Orchis purpurea (Huds) seedlings, which were selected as seeds and grouped according to their size, was intended to be examined for a period of two years. Canonical correlation analysis was used to explain whether there was a relationship between the parameters examined and the relationship between the two sets of variables in terms of the phases in which they were taken, and their contributions to variance. Leaf area prediction modeling was performed for Orchis purpurea Huds. by applying multiple regression analysis to leaf characteristics.

\section{MATERIAL AND METHODS}

\section{Material}

Seedlings of Orchis purpurea Huds, the trial material were collected from the forest area $\left(41^{\circ} 23^{\prime} 14.19^{\prime \prime} \mathrm{N}\right.$, $35^{\circ} 35^{\prime} 04.53$ "E, $945 \mathrm{~m}$ high from sea level) in Başkaya village of Bafra district of Samsun, Turkey in December 2017. Orchis purpurea Huds. species have 4-6 ovoid-rectangular shaped leaves close to base, with petals forming a spherical cone, densely speckled (Figure 1) with clusters of reddish-purple pustule clusters, and striped flowers on the side lobes [8]. Study material was created by dividing 72 individuals belonging to the genus into 8 groups with 9 individuals in each group according to their developmental status, and the visual, featuring two individuals from each group as their representatives, was presented in Figure 2. Such a classification was made since the limits of the vegetative parts are controlled by the size of the main tuber in salep orchids. In other words, every tuber planted continues its generation by creating a tuber slightly larger than itself $[36,37]$.

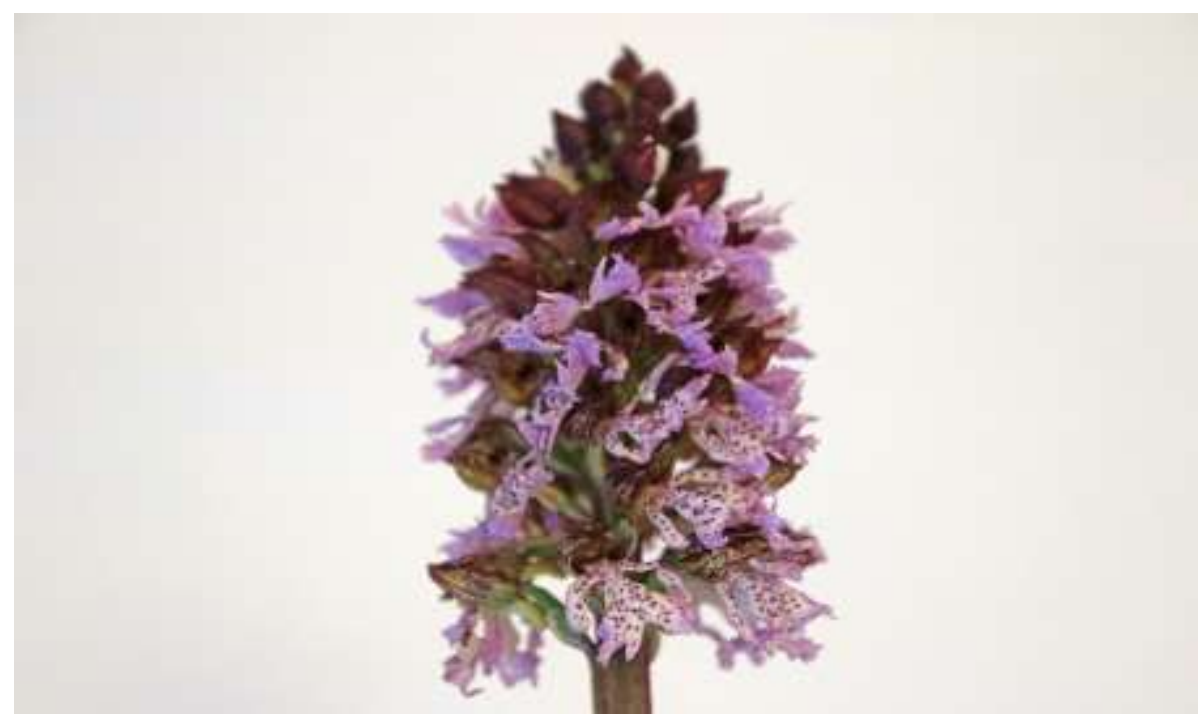

Figure 1. Collection of an adult flower of Orchis purpurea Huds. species 


\section{Methods}

\section{Setting up the experiment}

The research was carried out in the experimental area of Ondokuz Mayis University in 2018-2019, with three repetitions, each of which consisted of three individuals. Seedlings seen in Figure 2 were filled with peat, whose chemical and physical properties were presented in Table 1, and planted in pots $15 \mathrm{~cm}$ in diameter on December 15, 2017, and left to their natural process. Average seedling length, tuber width and tuber length measurements of seedlings are given in Table 2. Vegetation was terminated on May 20, 2018 (Figure 3), and the mean values of plant height, tuber width, tuber length, tuber fresh weight, tuber dry weight, number of leaves, leaf width and leaf length taken on this date are given in Table 3. In the second year of the study, the procedures carried out in the previous year for the seedlings of Orchis purpurea Huds. species obtained from the same location on 13 December 2018 were repeated. The second year vegetation of the study was terminated on May 16, 2019.

\section{Evaluation of data}

Anova and Duncan's multiple comparison tests

The data obtained from the study were subjected to variance analysis according to randomized block design with 3 replications, and two-year averages were interpreted with Duncan's multiple comparison test. SPSS software package was used for the evaluation of all data.

Table 1. Main chemical and physical properties and average amount of added nutrients for peat tested

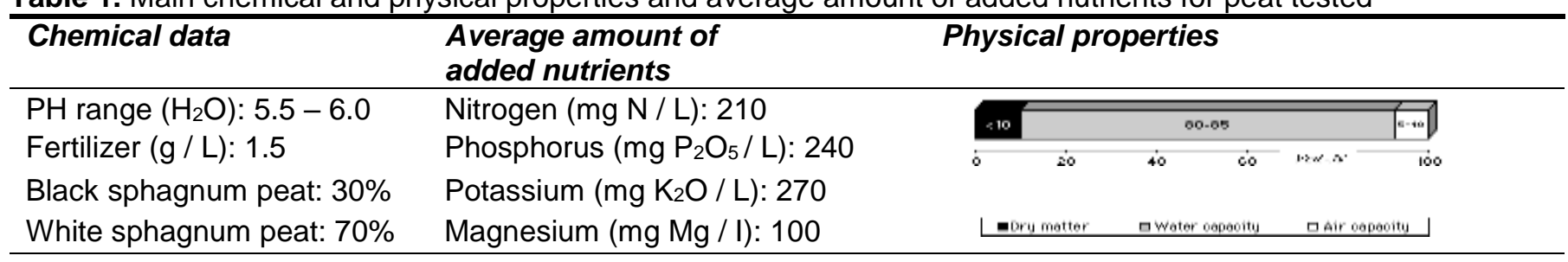

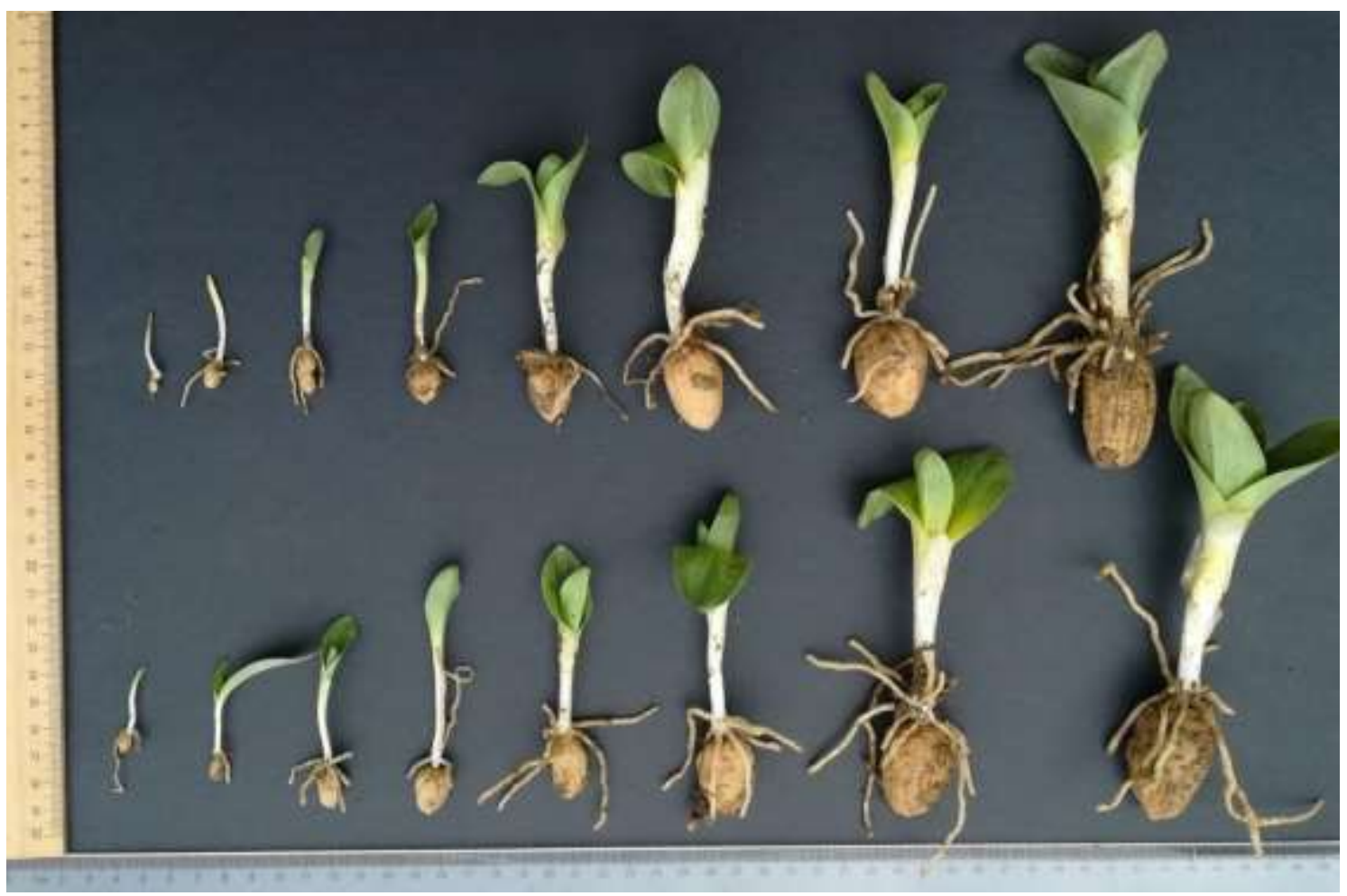

Figure 2. Orchis purpurea Huds. seedlings examples which were divided into eight classes according to their biomass size 
Canonical correlation analysis (CCA)

In the simplest correlation analysis known in statistics, the relationship between two variables $\left(Y_{i}, X_{i}, i=1\right.$, $2, \ldots n)$ is determined by simple correlation coefficient. The relationship between a dependent variable $(Y)$ and more than one independent variable $\left(X_{1}, X_{2}, \ldots X n\right)$ is examined by multiple correlation analysis and by calculating partial correlations. In CCA, the most complex relationship analysis, the relationship between two sets of data $\left(X: X_{1}, X_{2}, \ldots X_{p}\right.$ and $\left.Y: Y_{1}, Y_{2}, \ldots Y_{q}\right)$, each containing more than one variable, is investigated with the help of correlations between the linear components selected from these two sets [53]. CCA is applied to determine the correlation between linear combinations of variables in one set of variables $(X$ variable set, qX1) called the canonical variable $V$ and linear combinations of variables in another set of variables ( $Y$ variable set, $p x 1$ ) called the canonical variable $U$ [54]. In order to reflect the relationship between measurements taken at the time of planting and harvesting of Orchis purpurea Huds. seedlings, canonical variables $(U$ and $V$ ) are created in such a form that canonical variable pairs $\left(U_{i} V_{i}\right)$ are independent of each other, and the estimated canonical correlation coefficient $\left(r_{i}\right)$ between the first canonical variable pair $\left(U_{1} V_{1}\right)$ is maximum [55]. While canonical variables are explained as symbols $U_{i}=Y_{a i}$ and $V_{i}=X_{b i}$, the coefficients $a_{i}$ and $b_{i}$ in the equation are standardized canonical coefficients of $p \times 1$ and $q \times 1$, respectively [56]. In order for CCA to be performed, some assumptions must be met in the data set. These assumptions can be summarized as the properties showing normal distribution with multiple variables and the absence of multicollinearity between the properties, and the sample width being 5 times the number of variables in terms of reliability according to the results obtained [40]. The canonical correlation coefficient, which is a measure of the relationship between $X$ and $Y$ variable sets, is estimated by the following equation [39]:

$$
P u_{1} v 1=r_{i}=\sqrt{\lambda_{i}}=\frac{\operatorname{Cov}(U, V)}{\sqrt{\operatorname{Var}(U) \operatorname{Var}(V)}}=\frac{a^{\prime} \sum_{12} b}{\sqrt{\left(a^{\prime} \sum_{11} a\right)\left(b^{\prime} \sum_{22} b\right)}} ; i=1,2, \ldots, p
$$

Multiple regression model

When multiple independent variables that affect the dependent variable are encountered, multiple linear regression analysis is used to determine the relationship between the dependent variable and independent variables. Multiple linear regression analysis examines which independent variable or variables have significant effect on dependent variable. In statistics, the multiple linear regression model is expressed mathematically as follows.

$$
Y=\beta_{0}+\beta_{1} X_{1}+\beta_{2} X_{2}+\cdots+\beta_{p} X_{p}+\varepsilon
$$

Here, $Y$ is a dependent variable while $X$ is an independent variable. The number of variables is $p$ and the parameter values are $\beta j(j=1,2, \ldots, p)$. Multiple linear regression model can also be expressed with matrix representation.

$$
Y=\left[\begin{array}{c}
Y_{1} \\
Y_{2} \\
\vdots \\
Y_{n}
\end{array}\right]_{n x 1}, X=\left[\begin{array}{ccccc}
1 & X_{11} & X_{21} & \ldots & X_{p 1} \\
1 & X_{12} & X_{22} & \ldots & X_{p 2} \\
\vdots & \vdots & \vdots & \ldots & \vdots \\
1 & X_{1 n} & X_{2 n} & \ldots & X_{p n}
\end{array}\right]_{n x(p+1)}, \beta=\left[\begin{array}{c}
\beta_{0} \\
\beta_{1} \\
\vdots \\
\beta_{n}
\end{array}\right]_{(p+1) x 1}, \varepsilon=\left[\begin{array}{c}
\varepsilon_{0} \\
\varepsilon_{1} \\
\vdots \\
\varepsilon_{n}
\end{array}\right]_{n x 1} \quad Y=X \beta+\varepsilon
$$

\section{RESULTS AND DISCUSSION}

This study, in which the species Orchis purpurea Huds. was used as plant material, was conducted for two years (2018 - 2019). Pre-planting seedling height, seedling tuber width and seedling tuber length and post-harvest plant height, tuber width, tuber length, tuber fresh weight, tuber dry weight, number of leaves, leaf width, leaf length, total leaf area, means of leaf area characteristics were examined in seedlings collected and divided into eight different groups according to the size of their biomass. The statistical analyzes performed using the data obtained are presented as items.

\section{Comparison of morphological characteristics of seedling groups}

Seedlings in the research were divided into eight groups according to their morphological characteristics. In these groups, variance analysis was performed according to seedling height, seedling tuber width, and seedling tuber length properties and the results were analyzed according to Duncan's multiple comparison test (Table 2). Within seedling groups, the best results according to all characteristics were obtained from seedling group number eight. 


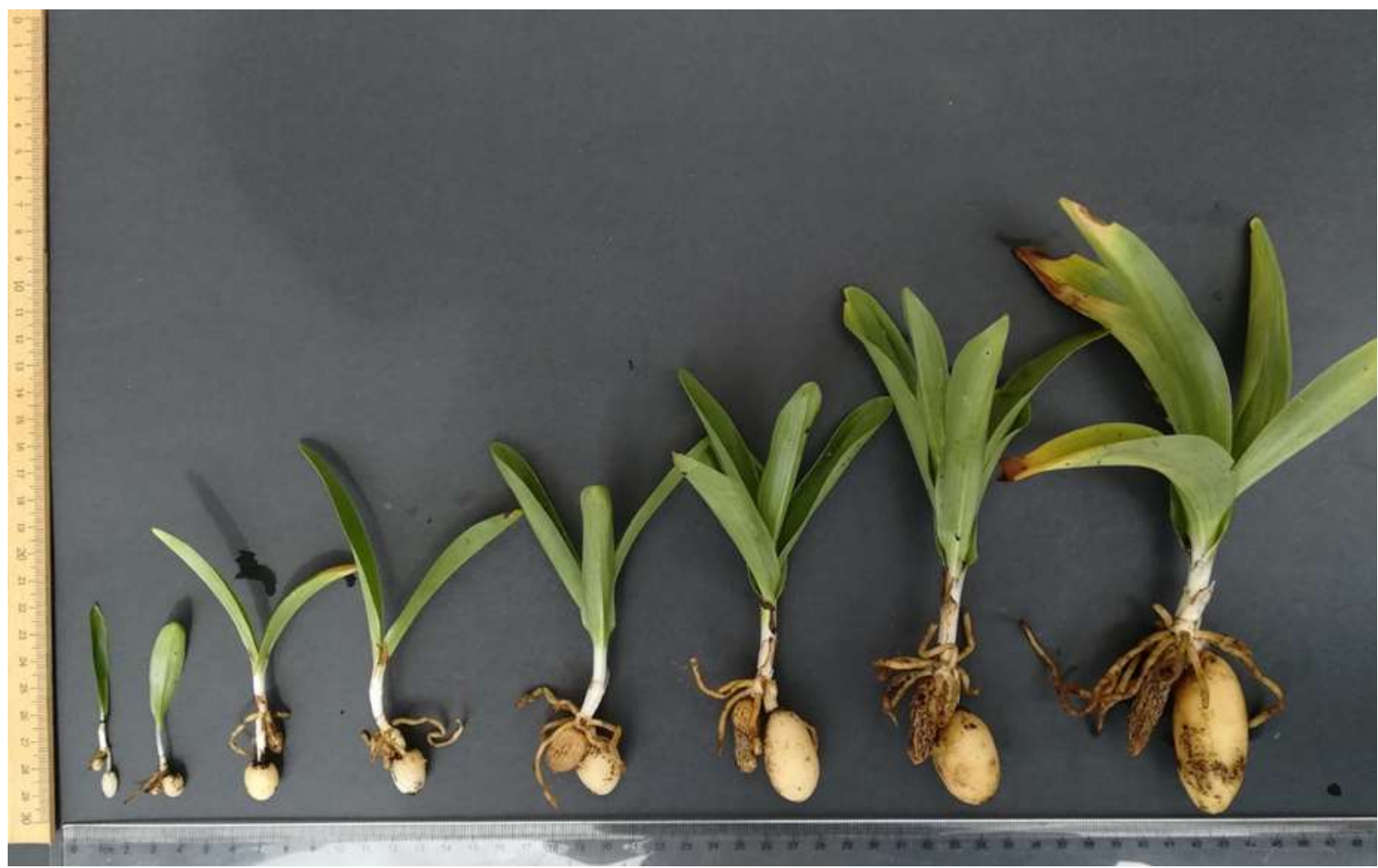

Figure 3. Orchis purpurea Huds. plant samples for each group at the end of vegetation

It was found that there was a significant difference between the groups depending on the years. This indicates an increase in seedling height, seedling tuber width, and seedling tuber length depending on years.

In addition, plant height, tuber width, tuber length, tuber fresh weight, tuber dry weight, number of leaves (per/plant), leaf width $(\mathrm{mm})$, leaf length $(\mathrm{mm})$, total leaf area $\left(\mathrm{mm}^{2}\right)$, means of leaf area $\left(\mathrm{mm}^{2}\right)$ characteristics were examined according to seedling groups (Table 3). According to these results, when all characteristics are taken into account, the best results are obtained from group eight. Depending on the years, there are very significant differences between all characteristics, except plant height. The increase in the size of the tuber over the years positively affects other properties as well.

Table 2. Means and significance of investigated parameters of Orchis purpurea Huds. in planting date

\begin{tabular}{lcccccc}
\hline Seedling groups & \multicolumn{2}{l}{$\begin{array}{l}\text { Seedling height } \\
\text { (cm) }\end{array}$} & $\begin{array}{l}\text { Seedling tuber width } \\
\text { (mm) }\end{array}$ & $\begin{array}{l}\text { Seedling } \\
\text { length(mm) }\end{array}$ & tuber \\
\hline $\mathbf{1}$ & 3.89 & $\mathrm{~g}$ & 3.73 & $\mathrm{~g}$ & 5.29 & $\mathrm{f}$ \\
$\mathbf{2}$ & 5.10 & $\mathrm{f}$ & 4.24 & $\mathrm{~g}$ & 6.35 & $\mathrm{f}$ \\
$\mathbf{3}$ & 6.23 & $\mathrm{e}$ & 7.22 & $\mathrm{f}$ & 10.08 & $\mathrm{e}$ \\
$\mathbf{4}$ & 9.16 & $\mathrm{~d}$ & 9.17 & $\mathrm{e}$ & 12.39 & $\mathrm{e}$ \\
$\mathbf{5}$ & 9.86 & $\mathrm{~d}$ & 12.00 & $\mathrm{~d}$ & 16.43 & $\mathrm{~d}$ \\
$\mathbf{6}$ & 10.79 & $\mathrm{c}$ & 15.45 & $\mathrm{c}$ & 22.40 & $\mathrm{c}$ \\
$\mathbf{7}$ & 11.98 & $\mathrm{~b}$ & 19.48 & $\mathrm{~b}$ & 27.18 & $\mathrm{~b}$ \\
$\mathbf{8}$ & 14.68 & $\mathrm{a}$ & 24.39 & $\mathrm{a}$ & 34.49 & $\mathrm{a}$ \\
Mean & 8.96 & & 11.96 & & 16.82 & \\
\hline Mean Square and Significance & & & & & \\
\hline Year (Y) & 156.24 & $*$ & 1898.07 & $* *$ & 3120.19 & $*$ \\
Grup (G) & 80.60 & $* *$ & 326.44 & $* *$ & 650.10 & $*$ \\
Y $\times$ G & 2.51 & $* *$ & 93.57 & $*$ & 171.43 & $*$ \\
Error & 0.37 & & 2.72 & & 6.20 & \\
\hline
\end{tabular}

${ }^{*} ; p<0.05,{ }^{* *} ; p<0.01$. Values followed by different letters in each column are significantly different $(p<0.01)$ according to Duncan Test.

In this study, descriptive statistics of two-year average data (Table 2, 3) are given in Table 4, in which vegetative characteristics of Orchis purpurea Huds. species are discussed. There has been no study in which the vegetative characteristics of this species have been identified. Vegetative characteristics belonging to some other species (Ophrys lutea, Serapias vomeracea, Ophrys mammosa, Ophrys umbilicata, Orchis Brazilian Archives of Biology and Technology. Vol.63: e20190769, 2020 www.scielo.br/babt 
sancta, Dactylorhiza romana) of the same family and used as salep orchids have been reported in a small number of studies. These studies were not included due to the wide variation between the vegetative characteristics described in these studies, which dealt with different genera and species, and the characteristics of the species Orchis purpurea Huds. The main tuber size controls the morphological characteristics of the species used as the salep orchid. Within the family, Orchis purpurea Huds. is among the species containing high biomass [36, 37, 52].

Table 3. Means and significance of investigated parameters of Orchis purpurea Huds. in planting date

\begin{tabular}{|c|c|c|c|c|c|c|c|c|c|c|c|c|c|c|}
\hline $\begin{array}{l}\text { Seedling } \\
\text { groups }\end{array}$ & PH & TW & TL & TFW & & TDW & & NL & LW & LL & & TLA & MLA & \\
\hline$\overline{1}$ & $8.22 \mathrm{f}$ & $12.92 \mathrm{e}$ & $16.54 \mathrm{f}$ & 3.08 & $f$ & 0.56 & $\mathrm{e}$ & $2.33 \mathrm{~g}$ & $11.20 \mathrm{~d}$ & 48.07 & e & $737.56 \mathrm{f}$ & 324.44 & $\mathrm{e}$ \\
\hline 2 & $8.84 \mathrm{f}$ & $12.52 \mathrm{e}$ & $17.06 \mathrm{f}$ & 2.72 & $f$ & 0.45 & $\mathrm{e}$ & $2.33 \mathrm{~g}$ & $11.47 \mathrm{~d}$ & 46.77 & e & $713.92 \mathrm{f}$ & 301.86 & e \\
\hline 3 & $10.77 \mathrm{e}$ & $22.84 \mathrm{~d}$ & 24.39 e & 6.65 & e & 1.49 & $d$ & $3.33 \mathrm{f}$ & $15.79 \mathrm{c}$ & 57.15 & e & 1864.46 ef & 564.18 & e \\
\hline 4 & $14.26 \mathrm{~d}$ & $25.45 \mathrm{~d}$ & $29.16 \mathrm{e}$ & 8.01 & e & 1.63 & $d$ & $4.33 \mathrm{e}$ & $18.05 \mathrm{c}$ & 71.63 & $d$ & $3665.01 \mathrm{e}$ & 856.97 & $d$ \\
\hline 5 & $14.01 \mathrm{~d}$ & $32.46 \mathrm{c}$ & $36.43 \mathrm{~d}$ & 11.83 & $d$ & 2.57 & $c$ & $5.17 \mathrm{~d}$ & $23.42 b$ & 89.67 & $c$ & $7482.68 \mathrm{~d}$ & 1440.18 & $C$ \\
\hline 6 & $15.55 \mathrm{c}$ & $34.32 \mathrm{c}$ & $47.96 \mathrm{c}$ & 15.78 & c & 3.05 & $\mathrm{c}$ & $6.50 \mathrm{c}$ & $25.18 b$ & 95.81 & $\mathrm{bc}$ & $11788.24 \mathrm{c}$ & 1802.27 & $b$ \\
\hline 7 & $18.04 \mathrm{~b}$ & $39.23 \mathrm{~b}$ & $53.21 \mathrm{~b}$ & 18.76 & $\mathrm{~b}$ & 4.21 & $b$ & $7.83 \mathrm{~b}$ & $25.86 \mathrm{~b}$ & 103.52 & $\mathrm{~b}$ & $14639.30 \mathrm{~b}$ & 1873.53 & $b$ \\
\hline 8 & $21.31 \mathrm{a}$ & $47.57 \mathrm{a}$ & $58.96 \mathrm{a}$ & 23.82 & $\mathrm{a}$ & 5.70 & $\mathrm{a}$ & $8.83 \mathrm{a}$ & $33.75 \mathrm{a}$ & 125.06 & $\mathrm{a}$ & $21244.98 \mathrm{a}$ & 2430.55 & $a$ \\
\hline Mean & 13.87 & 28.41 & 35.46 & 11.33 & & 2.46 & & 5.08 & 20.59 & 79.71 & & 7767.02 & 1199.25 & \\
\hline \multicolumn{15}{|c|}{ Mean Square and Significance } \\
\hline Year (Y) & $464.07^{* *}$ & $4961^{\star *}$ & $5369^{* *}$ & $1357.3^{\star *}$ & & $59.47^{\star \star}$ & & $126.7^{* *}$ & 7.76 & $388.1^{*}$ & & $202989464^{* *}$ & 6082.88 & \\
\hline Grup (G) & $122.24^{* *}$ & $915.4^{\star *}$ & $1614^{\star *}$ & $348.46^{* *}$ & & $19.88^{* *}$ & & $36.33^{* *}$ & $369.2^{\star *}$ & $4836^{* *}$ & & $339395066^{* *}$ & $3843023^{* *}$ & \\
\hline$Y \times G$ & 1.41 & $39.70^{\star *}$ & $42.62^{*}$ & $28.29^{\star *}$ & & $1.40^{* *}$ & & 0.66 & 3.98 & $275.4^{*}$ & & $15742569^{* *}$ & 338.63 & \\
\hline Error & 0.87 & 11.96 & 17.93 & 5.70 & & 0.38 & & 0.50 & 4.79 & 89.17 & & 3252204 & 45527.10 & \\
\hline
\end{tabular}

${ }^{*} ; p<0.05,{ }^{* *} ; p<0.01$. Values followed by different letters in each column are significantly different $(p<0.01)$ according to Duncan Test. PH; Plant height (cm), TW; Tuber width (mm), TL; Tuber length (mm), TFW; Tuber fresh weight (g), TDW; Tuber dry weight $(\mathrm{g})$, NL; Number of leaves (per/plant), LW; Leaf width (mm), LL; Leaf length (mm), TLA; Total leaf area $\left(\mathrm{mm}^{2}\right)$, MLA; Means of leaf area $\left(\mathrm{mm}^{2}\right)$.

\section{Canonical correlation analysis}

The CCA was performed to examine and explain the relationship between two sets of variables (planting and harvest characteristics). For this analysis, the data of Orchis purpurea Huds. measured in 2018-2019 were used. For this, the three parameter data in Table 1 were used, by ignoring seedling groups, and a variable set of "planting parameters" consisting of three variables was formed. For the second set of variables, the data of the ten parameters seen in Table 2 were used by ignoring seedling groups, and a variable set of "harvest parameters" consisting of ten variables was formed. The relationship between the variable sets of "planting parameters" and "harvest parameters" of salep orchids and the contribution of each set of variables, if any, to this relationship was examined and explained by CCA in Orchis purpurea Huds.

Since CCA examines the complex relationship structure between variable sets, the difficulties in interpreting the results have put the use of this analysis technique into the background. However, in the biological studies, examining the relationship structure between the characteristics focused on by CCA and not by simple correlation coefficients, without disturbing the relationship structure between these characteristics, will provide more information to the researchers [40]. In recent years, studies evaluating biological data by using multivariate statistical approaches have been frequently encountered. Vainionpaa and coauthors [58] applied CCA in order to determine the factors that make up quality and to examine the relationship between quality characteristics and production factors in a data set containing different structural and saturation characteristics of different potato cultures. In the results of their study on Karayaka hoggets, Cankaya and coauthors [39] stated that explaining the relationships between morphological characteristics taken in different periods with CCA would provide time and financial gain by contributing to selection. Xian$\mathrm{Li}$ and coauthors [59] explained the relationship between vegetation, soil and topography, and Ekana and Orimoogunje [60] explained the multivariate relationships between vegetative characteristics of plant communities and soil in forest, fallow and fields, where cocoa was grown, with CCA [38]. Soganci [61] used CCA to determine the relationship between some agronomic characteristics affecting yield in 246 local dried bean genotypes collected from 8 locations.

Descriptive statistics of the parameters discussed in the study are given in Table 4 . The table indicates that when a 9-cm tall Orchis purpurea Huds. seedling with a diameter of $12 \times 17 \mathrm{~mm}$ tuber is planted; it can form a tuber of $28 \times 35 \mathrm{~mm}$ size at the end of the season (Table 4). 
Table 4. Descriptive statistics for investigated parameters of Orchis purpurea Huds.

\begin{tabular}{|c|c|c|c|}
\hline \multicolumn{2}{|c|}{ Set of variables I. (Planting parameters) } & \multicolumn{2}{|c|}{ Set of variables II. (Harvest parameters) } \\
\hline Variables & $\underline{X} \pm S_{x}$ & Variables & $\underline{X} \pm S_{\underline{x}}$ \\
\hline Seedling's height $(\mathrm{cm})$ & $8.960 \pm 0.576$ & Plant height $(\mathrm{cm})$ & $13.874 \pm 0.776$ \\
\hline Seedling's tuber width (mm) & $11.958 \pm 1.478$ & Tuber width (mm) & $28.414 \pm 2.309$ \\
\hline \multirow[t]{8}{*}{ Seedling's tuber length ( $\mathrm{mm}$ ) } & $16.824 \pm 2.005$ & Tuber length (mm) & $35.463 \pm 2.788$ \\
\hline & & Tuber fresh weight $(\mathrm{g})$ & $11.331 \pm 1.361$ \\
\hline & & Tuber dry weight (g) & $2.458 \pm 0.313$ \\
\hline & & Number of leaves (per/plant) & $5.083 \pm 0.422$ \\
\hline & & Leaf width $(\mathrm{mm})$ & $20.589 \pm 1.109$ \\
\hline & & Leaf length $(\mathrm{mm})$ & $79.710 \pm 4.159$ \\
\hline & & Total leaf area $\left(\mathrm{mm}^{2}\right)$ & $7767.020 \pm 1112.673$ \\
\hline & & Mean leaf area $\left(\mathrm{mm}^{2}\right)$ & $1199.248 \pm 112.133$ \\
\hline
\end{tabular}

$\underline{X}:$ Means of investigated parameters, $S_{\underline{x}}:$ Standart error

Correlation coefficients of pair relationships of the investigated characteristics and their significance controls are given in Table 5. When the table is examined, it is seen that all relations are significant at $p<0.01$ level. In the planting variable set, the strongest positive correlation was found between seedling's tuber width and seedling's tuber length $\left(0.988^{* *}\right)$. In the harvest variable set, the strongest positive relationships within the set were between tuber width, length, fresh and dry weight. The positive and very significant $\left(0.982^{* *}\right)$ relationship of tuber length with tuber fresh yield according to tuber width was noteworthy.

Table 5. Correlation matrix results for investigated parameters of Orchis purpurea Huds.

\begin{tabular}{|c|c|c|c|c|c|c|c|c|c|c|c|c|c|}
\hline $\begin{array}{l}\text { Variabl } \\
\text { es }\end{array}$ & SH & STW & STL & PH & TW & TL & TFW & TDW & NL & LW & LL & TLA & MLA \\
\hline SH & 1 & & & & & & & & & & & & \\
\hline STW & $.905^{\star *}$ & 1 & & & & & & & & & & & \\
\hline STL & $.910^{* *}$ & $.988^{\star *}$ & 1 & & & & & & & & & & \\
\hline PH & $.958^{\star *}$ & $.911^{\star \star}$ & $.918^{* *}$ & 1 & & & & & & & & & \\
\hline TW & $.927^{\star \star}$ & $.920^{\star *}$ & $.907^{\star *}$ & $.932^{* *}$ & 1 & & & & & & & & \\
\hline TL & $.935^{* *}$ & $.893^{* *}$ & $.910^{* *}$ & $.944^{* *}$ & $.958^{* *}$ & 1 & & & & & & & \\
\hline TFW & $.916^{* *}$ & $.903^{* *}$ & $.911^{* *}$ & $.919^{* *}$ & $.975^{\star *}$ & $.982^{* *}$ & 1 & & & & & & \\
\hline TDW & $.915^{\star \star}$ & $.901^{\star *}$ & $.907^{* *}$ & $.910^{* *}$ & $.964^{* *}$ & $.962^{\star \star}$ & $.989^{* *}$ & 1 & & & & & \\
\hline NL & $.949^{* *}$ & $.922^{\star *}$ & $.917^{\star *}$ & $.964^{* *}$ & $.933^{* *}$ & $.947^{\star *}$ & $.927^{\star \star}$ & $.914^{* *}$ & 1 & & & & \\
\hline LW & $.856^{\star *}$ & $.711^{\star *}$ & $.726^{* *}$ & $.788^{* *}$ & $.746^{* *}$ & $.786^{\star *}$ & $.761^{* \star}$ & $.781^{* \star}$ & $.801^{* *}$ & 1 & & & \\
\hline LL & $.866^{\star \star}$ & $.752^{* *}$ & $.758^{* *}$ & $.799^{* *}$ & $.742^{* *}$ & $.777^{\star \star}$ & $.744^{\star \star}$ & $.764^{* *}$ & $.812^{* *}$ & $.956^{\star *}$ & 1 & & \\
\hline TLA & $.912^{\star *}$ & $.876^{\star *}$ & $.890^{* *}$ & $.878^{* *}$ & $.845^{\star *}$ & $.885^{\star *}$ & $.881^{* \star}$ & $.897^{* *}$ & $.910^{* *}$ & $.908^{* *}$ & $.920^{\star *}$ & 1 & \\
\hline MLA & $.816^{\star *}$ & $.653^{\star *}$ & $.677^{\star *}$ & $.736^{* *}$ & $.714^{\star *}$ & $.777^{\star \star}$ & $.752^{* \star}$ & $.774^{* *}$ & $.751^{* *}$ & $.945^{* *}$ & $.930^{\star *}$ & $.905^{* *}$ & 1 \\
\hline
\end{tabular}

${ }^{*} ; \mathrm{p}<0.05,{ }^{* *} ; \mathrm{p}<0.01, \mathrm{SH}$; Seedling height $(\mathrm{cm})$, STW; Seedling's tuber width $(\mathrm{mm})$, STL; Seedling's tuber length $(\mathrm{mm})$, PH; Plant height $(\mathrm{cm})$, TW; Tuber width $(\mathrm{mm})$, TL; Tuber length $(\mathrm{mm})$, TFW; Tuber fresh weight $(\mathrm{g})$, TDW; Tuber dry weight (g), NL; Number of leaves (per/plant), LW; Leaf width $(\mathrm{mm})$, LL; Leaf length $(\mathrm{mm})$, TLA; Total leaf area $\left(\mathrm{mm}^{2}\right)$, $\mathrm{MLA}$; Mean leaf area $\left(\mathrm{mm}^{2}\right)$.

When the correlation coefficients between variable sets were evaluated, the highest positive correlation $\left(0.958^{* *}\right)$ was between the seedling height planted and the plant height harvested. The positive relationship between plant height and number of leaves means that the increase in seedling height planted can indirectly contribute to tuber yield with the increase in photosynthetic products. In the study, 3 pairs of canonical variables are obtained when there are 3 variables in the planting characteristics variable set and when there are 10 variables in the harvest characteristics variable set.

Table 6. Multivariate tests of significance $(S=3, M=3, N=131 / 2)$

\begin{tabular}{llllll}
\hline Test Name & Value & Approximate $\mathbf{F}$ & Hypothesis DF & Error DF & Significance of $\mathbf{F}$ \\
\hline Pillais & 2.261 & 11.312 & 30.00 & 111.00 & 0.00 \\
Hotellings & 43.213 & 48.495 & 30.00 & 101.00 & 0.00 \\
Wilks & 0.003 & 21.296 & 30.00 & 103.41 & 0.00 \\
Roys & 0.975 & & & & \\
\hline
\end{tabular}

DF; Degree of freedom 
When performing CCA, it is first checked whether the established canonical model is significant. Table 6 shows the results of Pillai's criterion, Hotelling's trace, Wilk's lambda and Roy's GCR tests. In general, Wilk's $\lambda$ is preferred by researchers as the most useful one [62]. According to these results, the canonical model created is statistically significant [Wilk's $\lambda=0.003, F(30,103.41)=21.296, p<0.001$ ]. Therefore, it can be said that there is a significant relationship between "planting characteristics" and "harvest characteristics" variable sets. Wilk's $\lambda$ test statistic is used for testing the null hypothesis that the given canonical correlation and all smaller ones are equal to zero in the population [63]. Some researchers interpret the effect size of the relationship with the inverse value of Wilk's $\lambda$ [53]. Therefore, it can be calculated as 1 - Wilk's $\lambda=1-0.003$ $=0.997[(1-0.975) \times(1-0.701) \times(1-0.584)=0.003]$. Accordingly, the shared variance between the two sets of variables is $99.7 \%$.

Table 7. Eigenvalues and canonical correlations

\begin{tabular}{lllllll}
\hline Root & Eigenvalue & Percent $(\%)$ & $\begin{array}{l}\text { Cumulative } \\
(\%)\end{array}$ & percent & $\begin{array}{l}\text { Canonical } \\
\text { Correlation }\end{array}$ & Squared Correlations \\
\hline $\mathbf{1}$ & 39.463 & 91.322 & 91.322 & 0.988 & 0.975 \\
$\mathbf{2}$ & 2.344 & 5.425 & 96.747 & 0.837 & 0.701 \\
$\mathbf{3}$ & 1.406 & 3.255 & 100.00 & 0.764 & 0.584 \\
\hline
\end{tabular}

While the established canonical model is meaningful, it needs to be tested in each canonical function. In Table 7, eigenvalues and canonical correlations are given for the three canonical functions developed for the model. When the table is examined, it is seen that the canonical correlation of the first canonical function is 0.988 , and this function explains $97.5 \%$ of the variance between two sets of variables. The contribution of the second and third canonical functions is $70.1 \%$ and $58.4 \%$, respectively, and it is seen that it contributes to the explanation of the variance between two sets of variables in all three functions, the highest being the first function.

Table 8. Dimension reduction analysis

\begin{tabular}{llllll}
\hline Roots & Wilks $\boldsymbol{\lambda}$ & $\mathbf{F}$ & Hypothesis DF & Error DF & Significance of F \\
\hline 1 TO 3 & 0.0031 & 21.2962 & 30.00 & 103.41 & 0.00 \\
2 TO 3 & 0.1243 & 7.3455 & 18.00 & 72.00 & 0.00 \\
3 TO 3 & 0.4157 & 6.5006 & 8.00 & 37.00 & 0.00 \\
\hline
\end{tabular}

DF; Degree of freedom

The results of the dimension reduction analysis used to evaluate the canonical functions are given in Table 8. Accordingly, there is a significant relationship between the variable sets of "planting parameters" and "harvest parameters" for all three functions ["Wilk's $\lambda=0.0031, F(30,103.41)=21.2962$ " and "Wilk's $\lambda=$ $0.1243, F(18,72.00)=7.3455$ " and "Wilk's $\lambda=0.4157, F(8,37.00)=6.5006$ ", $p<0.001$, respectively].

In Table 9, standardized canonical coefficients, structure coefficients, squares of structure coefficients, and communality coefficients are given for two canonical functions. Statistically, all 3 functions are significant. Here, the coefficients of the first two canonical functions are given in order to make comparisons. Standardized canonical coefficients (SC) give the contribution of each of the variables to canonical functions. Accordingly, the contributions of "planting characteristics" variables to the first canonical function are $\mathrm{SH}$ (0.4198), STW (0.7284) and STL (-0.1251), and the contribution of "harvest characteristics" variables to the canonical functions can be followed in Table 9 . In terms of the variable sets, tuber width variables $(0.7284$, 0.8172 , respectively) planted and harvested made the most important contribution to the first canonical function, and tuber length variables $(6.5556,2.9606$, respectively) planted and harvested made the most important contribution to the second canonical function. Canonical coefficients are the determinant coefficients used to estimate the values of the characteristics examined at the time of harvest, by using the morphological characteristics taken during planting. However, it is not appropriate to use these coefficients in case of multiple connections between the examined characteristics. Therefore, instead of these coefficients, it is necessary to use canonical loads that show the relationship between canonical variables and original variables [64]. That is, since the interpretation of standardized canonical correlations is not healthy, especially if there is multiple linear connection, it is a more accurate approach to interpret the structure coefficients given as correlations between canonical variables and both sets of variables [53].

When Table 9 is examined, it is seen that all variables have great contributions for the first canonical function. In terms of structure coefficients (Rc) signs, the evaluation is that those with the same signs are together, while those with different signs are in the opposite relationship. 
Table 9. Canonical association of planting and harvest parameters of Orchis purpurea Huds.

\begin{tabular}{lllllllr}
\multirow{2}{*}{ Variables } & \multicolumn{2}{l}{ Canonical function 1 } & \multicolumn{5}{l}{ Canonical function 2 } \\
\cline { 2 - 8 } & $\mathbf{S C}$ & $\mathbf{R c}$ & $\mathbf{R c}^{\mathbf{2}}$ & $\mathbf{S C}$ & $\mathbf{R c}$ & $\mathbf{R c}^{\mathbf{2}}$ & $\mathbf{h}^{\mathbf{2}}$ \\
\hline SH & 0.4198 & 0.9649 & 93.0993 & -0.9396 & -0.0235 & 0.0551 & 93.15 \\
STW & 0.7284 & 0.9845 & 96.9299 & -5.8025 & 0.0459 & 0.2104 & 97.14 \\
STL & -0.1251 & 0.9763 & 95.3240 & 6.5556 & 0.1882 & 3.5427 & 98.87 \\
PH & 0.1578 & 0.9630 & 92.7273 & 1.0153 & 0.0404 & 0.1631 & 92.89 \\
TW & 0.8172 & 0.9582 & 91.8071 & -2.2533 & -0.0813 & 0.6610 & 92.47 \\
TL & 0.3490 & 0.9407 & 88.4916 & 2.9606 & 0.1340 & 1.7961 & 90.29 \\
TFW & -0.6411 & 0.9401 & 88.3694 & 1.1359 & 0.0950 & 0.9019 & 89.27 \\
TDW & 0.0187 & 0.9388 & 88.1252 & -1.0759 & 0.0743 & 0.5519 & 88.68 \\
NL & -0.1920 & 0.9670 & 93.5070 & -2.8276 & -0.0314 & 0.0985 & 93.61 \\
LW & -0.0460 & 0.7961 & 63.3712 & 0.4090 & -0.0151 & 0.0227 & 63.39 \\
LL & 0.1826 & 0.8267 & 68.3482 & -0.6814 & -0.0514 & 0.2645 & 68.61 \\
TLA & 0.8094 & 0.9212 & 84.8628 & 2.4380 & 0.1145 & 1.3099 & 86.17 \\
MLA & -0.4746 & 0.7424 & 55.1187 & -1.2598 & 0.0362 & 0.1310 & 55.25 \\
\hline STH
\end{tabular}

Structure coefficients (Rc) greater than $|.45|$ are underlined. Communality coefficients $\left(\mathrm{h}^{2}\right)$ greater than $45 \%$ are underlined. SC; Standardized canonical function coefficient, Rc; Structure coefficients (canonical loading), Rc ${ }^{2}$; Squared structure coefficient (\%), $\mathrm{h}^{2}$; Communality coefficients (\%).

Since all variables in the first canonical function have structure coefficient with the same signs, as seedling size and planted tuber sizes grow, the yield and other characteristics that will occur at the time of harvest will also be increased. In the second function, where similar structure is seen in general, it can be interpreted that the size of the tuber planted rather than the length of the seedling contributes to yield and other properties at the time of harvest. The number of leaves and leaf sizes have a positive relationship with the length of the seedling planted. Although the $\mathrm{h}^{2}$ values of the leaf characteristics in the variable set of "harvest parameters" are greater than $45 \%$, they contribute less to the variance between the two sets of variables than the other parameters. According to these results, the most important positive contribution to the harvest characteristics is made by the tuber sizes planted, especially the tuber length $\left(\mathrm{h}^{2} ; 98.87\right)$. The data obtained from the tubers made the greatest contribution to the explanatory power of the canonical variables.

\section{Leaf area modeling}

Leaf area prediction models aim to estimate leaf area non-destructively and these models are important parameter in explaining some physiological events such as light intensity, photosynthesis, respiration, plant water consumption [65, 66]. Furthermore, these models enable researchers to carry out leaf area measurements on the same plants resulting in reduced experimental variability $[67,68]$.

Table 10. Analysis of variance for leaf areas of Orchis purpurea Huds.

\begin{tabular}{llllll}
\hline Source & DF & Sum of squares & Mean squares & F & Pr $>$ F \\
\hline Model & 2 & 49877966.587 & 24938983.293 & 534.464 & $<\mathbf{0 . 0 0 0 1}$ \\
Error & 80 & 3732936.551 & 46661.707 & & \\
Corrected Total & 82 & 53610903.137 & & & \\
\hline
\end{tabular}

Computed against model $\mathrm{Y}=$ Mean(Y). DF; Degree of freedom.

Before creating the model, variance analysis was performed to determine the relationship between the parameters. As a result of the analysis, it was found that there was a significant relationship between the characteristics that made up the model (Table 10). Leaf width and length were selected as the model parameters. As a result of the analysis made according to these two parameters, leaf area model was formed as follows (Table 11).

$$
\mathrm{LA}\left(\mathrm{mm}^{2}\right)=-1237.020+57.791 \times \mathrm{LW}+16.621 \times \mathrm{LL}
$$

Table 11. Model parameters (Leaf area, $\mathrm{mm}^{2}$ )

\begin{tabular}{lllllrr}
\hline Source & Value & $\begin{array}{l}\text { Standard } \\
\text { error }\end{array}$ & $\mathbf{t}$ & $\operatorname{Pr}>|\mathbf{t}|$ & $\begin{array}{r}\text { Lower bound } \\
(\mathbf{9 5 \% )}\end{array}$ & $\begin{array}{r}\text { Upper bound } \\
(\mathbf{9 5 \% )}\end{array}$ \\
\hline Intercept & -1237.020 & 92.163 & -13.422 & $<0.0001$ & -1420.430 & -1053.611 \\
Leaf width $(\mathrm{mm})$ & 57.791 & 5.386 & 10.731 & $<0.0001$ & 47.074 & 68.509 \\
Leaf length $(\mathrm{mm})$ & 16.621 & 1.580 & 10.517 & $<0.0001$ & 13.476 & 19.766 \\
\hline
\end{tabular}


When the leaf area values obtained with this model were compared graphically with the actual leaf area values, proximity of $93.25 \%$ was calculated (Figure 4). This value shows that the obtained mathematical model gives a highly accurate result.

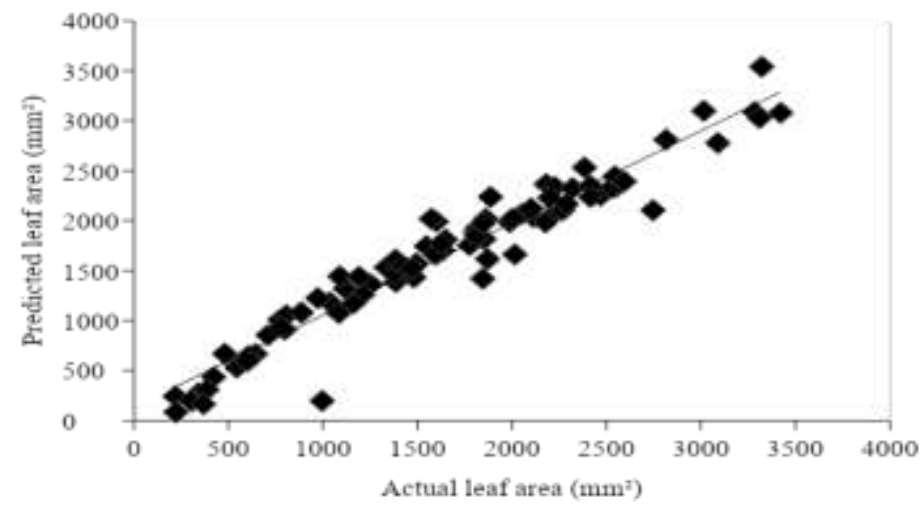

Figure 4. The relationship between actual leaf area $\left(\mathrm{mm}^{2}\right)$ and predicted leaf area $\left(\mathrm{mm}^{2}\right)$

\section{CONCLUSION}

The orchid seeds, which have a chance to germinate in nature, are able to produce a few tiny leaves and less than one gram of tubers in the first year. In salep orchids, which are annual plants, each tuber completes its life by producing a larger tuber during the vegetation period, and this cycle continues for many years. In this study, development performance, seedling characteristics and growth capacities of Orchis purpurea Huds. seedlings, which were divided into eight classes according to their size, were determined. According to the findings, all morphological characteristic revealed during the harvest period depend on the development state of the starting material. According to the canonical correlation results, the most important positive contribution to the harvest characteristics is made by the tuber sizes planted, especially the tuber length. The data obtained from the tubers made the greatest contribution to the explanatory power of the canonical variables. Leaf area prediction modeling performed with leaf characteristics yielded highly accurate results. More physiological studies should be carried out on salep, and especially the germination difficulty of seeds should be studied.

Funding: The research material was collected within the scope of the field studies of the project titled "Developing and Popularizing Salep Orchids by Culturing Them" supported by Yeşilırmak Basin Development Association. We would like to thank the Yeşilırmak Basin Development Association and the project team for providing this opportunity.

Acknowledgments: The authors are grateful to Aydan Ermis and Tuba Odabas (Ondokuz Mayis University, School of Foreign Languages) for editing English in this paper.

Conflicts of Interest: The authors declare no conflict of interest.

\section{REFERENCES}

1. Arditti J, Ghani AK. Numerical and physical properties of orchid seeds and their biological implications. New Phytol 2000; 145: 367-421.

2. Whigham WD, Willems JH. Demographic studies and life-history strategies of temperate terrestrial orcids as a basis for conservation. In Orchid conservation, Editors Dixon, K.W.; Kell, S.P.; Barrett, R.L.; Cribb, P.J. Natural History Publications (Borneo), Kota Kinabalu, Sabah, Malaysia, 2003. p. 137-58.

3. Pant B. Medicinal orchids and their uses: Tissue culture a potential alternative for conservation. Afr J Plant Sci 2013; 7(10): 448-67.

4. Addam K, Nisreen S, Hamdan MB, Mohammad H, Hout K. Ophrys holoserica (Burm.f.) Greuter subsp. Shoufensis subsp. novo K. Addam and M. Bou-Hamdan (Orchidaceae) A new world record from Lebanon. Int J Botany Stud 2018; 3(6): 25-32.

5. Govaerts R, Bernet P, Kratochvil K, Gerlach G, Carr G, Alrich P, Pridgeon AM, Pfahl J, Campacci MA, Holland BD, Tigges H, Shaw J, Cribb P, George A, Kreuz K, Wood JJ. World checklist of Orchidaceae. Facilitated by the Royal Botanic Gardens, Kew, London, UK, 2017; Published on the Internet; Available from: http://apps.kew.org/wcsp/ (accessed 19 December 2019).

6. Arditti J. Fundamentals of Orchid Biology. 1st ed., Publiser: John Wiley and Sons, New York, USA; 1992. 
7. De LC, Pathak P. Conservation, management and utilization of orchid genetic resources. Orchid Society of India 2018; 32: 81-91.

8. Renz J, Taubenheim G. Orchis L. (Orchidaceae), In Flora of Turkey and the East Aegean Islands Edinburgh, Editor P.H. Davis, Publiser: Edinburgh University Press, United Kingdom, 1984; p. 451-600.

9. Kasparek M, Grim U. Europen trade in Turkish salep with special reference to Germany. Econ Bot 1999; 53: 396406.

10. Kreziou A, De Boer H, Gravendeel B. Harvesting of salep orchids in Northwestern Greece continues to threaten natural populations. Oryx 2016; 50: 393-6.

11. Ghorbani A, Gravendeel B, Selliah S, Zarre S, de Boer H. DNA barcoding of tuberous Orchidoideae: A resource for identification of orchids used in Salep. Mol Ecol Resour 2017; 17: 342-52.

12. Tatiya A, Kalaskar M, Patil Y, Surana S. Chemical analysis, nutritional content and antioxidant property of Eulophia herbacea Lindl. tubers: a medicinally versatile Indian tribal nutritional food suplement. Indian J Tradit Know 2018; 17(1): 141-7.

13. Brinkmann JA. Quick scan of Orchidaceae species in European commerce as components of cosmetic, food and medicinal products. PC22 Doc. 22.1 Annex, 2014. Available online: https://cites.org/eng/com/pc/22/index.php (accessed on 12 December 2019).

14. Sezik E. Turkish orchids and salep. Acta Pharm Sci 2002; 44: 151-7.

15. Jagdale SP, Shimpi S, Chachad D. Pharmacological studies of 'Salep'. J Herb Med Toxic 2009; 3(1): 153-6.

16. Hossain MM. Therapeutic orchids: traditional uses and recent advances - an overview. Fitoterapia 2011; 82: 10240.

17. Ghorbani A, Gravendeel B, Zarre S, Boer H. Illegal wild collection and international trade of CITES listed terretrial orchid tubers in Iran. Traffic Bulletin 2014; 26: 53-8.

18. Parlak S. Determining the effectiveness of chemical and mechanical weed control methods in cultivated Anacamptis sancta parcels. J For Res 2016; 4(1): 126-33.

19. Mitchell RB. Growing hardy orchids from seeds at Kew. Plantsman 1989; 2: 152-69.

20. Warghat AR, Bajpai PK, Srivastava RB, Chaurasia P, Chauhan RS, Sood H. In vitro protocorm development and mass multiplication of an endangered orchid Dactylorhiza hatagirea. Turk J Bot 2014; 38: 737-46.

21. Ong JWL. In bed with viruses: the partnership between orchids, fungi and viruses. Dissertation, Murdoch University, Murdoch, Western Australia; 2016.

22. Cig A, Demirer Durak E, Isler S. In vitro symbiotic germination potentials of some Anacamptis, Dactylorhiza, Orchis and Ophrys terrestrial orchid species. Appl Ecol Env Res 2018; 16: 5141-55.

23. Ponert J, Vosolsebe $\mathrm{S}$, Kmecova K, Lipavska H. European orchid cultivation-from seed to mature plant. Eur J Environ Sci 2011; 1(20): 95-107.

24. Jacobsone G. Morphogenesisi of wild orchid Dactylorhiza fuchsii im tissue culture. Acta Univ Latv Biol 2008; 745 : 17-23.

25. Baskin CC, Baskin JM. Seeds, Ecology, Biogeography, and Evolution of Dormancy and Germination. 1st ed.; Publiser: Academic Press, San Diego, USA; 1998.

26. Caliskan O. Middle Black Sea Region sahlep orchid species and tuber properties. Anadolu J Agr Sci 2019; 34(1): 78-83.

27. Bektas E, Cuce M, Sokmen A. In vitro germination, protocorm formation, and plantlet development of Orchis coriophora (Orchidaceae), a naturally growing orchid species in Turkey. Turk J Bot 2013; 37: 336-42.

28. Rasmussen HN. Terrestrial orchids from seed to mycotrophic plant. 1st ed.; Publiser: Cambridge University Press, Cambridge, UK; 1995.

29. Coelho IS, Queiroz MV, Costa MD, Kasuya MCM, Araujo EF. Production and regeneration of protoplasts from orchid mycorrihizal fungi Epulorhiza repens and Ceratorhiza sp. Braz Arch Biol Technol 2010; 53: 153-9.

30. Pedroso-de-Moraes C, Souza MC, Ronconi CC, Marteline MA. Response of Cattleya hybrids for Fusarium oxysporum f. sp. cattleyae foster. Braz Arch Biol Technol 2011; 54: 267-71.

31. Utami ESW, Hariyanto S, Manuhara YSW. In vitro propagation of the endangered medicinal orchid, Dendrobium lasianthera J.J.Sm through mature seed culture. Asian Pac J Trop Biomed 2017; 7(5): 406-10.

32. Knees SG. Import and export of orchids and the law. In Modern Methods in Orchid Conservation, Editor H. Pritchard, Publiser: Cambridge University Press, United Kingdom, 2004; p. 163-170.

33. IUCN. 2017. The IUCN Red List of Threatened Species, Version 2016-3, 2017. Available online: www.iucnredlist.org (accessed on 15 December 2019).

34. Swarts ND, Dixon KW. Terrestrial orchid conservation in the age of extinction. Ann Bot 2009; 104: 543-56.

35. Caliskan O, Kurt D, Korkmaz H. Studies on Samsun sahlep orchid varieties. J Med Plants Stud 2018; 6(6): 171-4.

36. Caliskan O, Kurt D. Description of development period of Dactylorhiza romana (Sebast.) Soo. during four consecutive years. Anadolu J Agr Sci 2019; 34(2): 195-200. 
37. Caliskan O, Kurt D, Cirak C. Development of new sustainable sahlep production methods using Ophrys sphegodes subsp. mammosa (Desf.) Soo ex E. Nelson. J Agr Sci Tech 2019; 21(6): 1547-55.

38. Saglam M. The estimation with canonical correlation analysis of relationships between physical and chemical properties in entisol and inceptisol soils. J Faculty Agr SD Univ 2013; 8(2): 66-79.

39. Cankaya S, Altop A, Olfaz M, Erener G. Canonical correlation analysis for estimation for relationships between some traits measured at pre- and post- slaughtering periods in Karayaka hoggets. Anadolu J Agr Sci 2009; 24(1): 61-6.

40. Keskin S, Kor A, Baspinar E. The investigation of relationships between some traits measured pre-slaughtering and post-slaughtering by using of canonical correlation analysis in Akkeçi Kids. J Agr Sci 2005; 11(2): 154-9.

41. Ozcomak MS, Gunduz, M, Demirci A, Yakut E. Investigation of relationship between various climate and product data by canonical correlation analysis and data envelopment analysis methods. J Econ Admin Sci 2012; 26(1): 111-31.

42. Albayrak A.S. Applied Multivariate Statistical Techniques. 1st ed.; Publiser: Asil Publications, Ankara, Turkey; 2006.

43. Odabas MS, Camas N, Cirak C, Radusiene J, Valdamiras J, Ivanauskas L. The quantitative effects of temperature and light intensity on phenolics accumulation in St. John's Wort (Hypericum perforatum L.). Nat Prod Commun 2010; 5(4): 535-40.

44. Odabas MS, Leelaruban N, Simsek H, Padmanabhan G. Quantifying impact of droughts on barley yield in North Dakota, usa using multiple linear regression and artificial neural network. Neural Netw World 2014; 24(4): 343-55.

45. Duvey DS, Bateman RM, Fay MF, Hawkins JA. Friends or relatives? Phylogenetics and species delimitation in the controversial European orchid genus Ophrys. Ann Bot 2008; 101: 385-402.

46. Addam K, Kebbe ID, Takkoush J, Hout K, Bou Hamdan M. A new variety from Lebanon Ophrys apifera var. Liberica (Orchidaceae). J Botan Res 2015; 6(1): 39-46.

47. Delforge P. Orchids of Europe, North Africa and the Middle East. 1st ed.; Publiser: A\&C Black, London, UK; 2006.

48. Sevgi E, Altundag E, Kara O, Sevgi O, Tecimen H, Bolat I. Morphological, anatomical and ecological studies on some Orchis (Orchidaceae) taxa of Mediterranean region, Turkey. J Environ Biol 2012; 33(2 Suppl): 343-53.

49. Beczala T, Chumura D, Jonderko T. A new locality of orchid Orchis purpurea Huds. in Cieszyn Foothills (Czech Republic). Acta Mus Sil Sci Nat 2016; 65: 63-4.

50. Tsiftsis S, Djordjevic V. Habitat effects and differences in the reproductive success of Orchis punctulata and Orchis purpurea (Orchidaceae). Turk J Bot 2018; 42: 400-11.

51. Tahir HR. The anatomical structure of the Orchis purpurea Huds. Int J Adv Res Biol Sci 2019; 6(8): 24-8.

52. Ertas S, Ozel A, Erden K. Determination of the botanical properties and glucomannan contents of some salep species cultivated in Şanlıurfa conditions. Harran J Agr Food Sci 2019; 23(1): 39-46.

53. Temurtas A. Canonical correlation analysis. In Multivariate statistics for all. Editor Guzeller C.O., Publiser: Maya Academy Publication, Ankara, Turkey, 2016; pp. 101-12.

54. Gunderson BK, Muirhead RJ. On estimating the dimensionality in canonical correlation analysis. J Multivariate Anal 1997; 62: 121-36.

55. Johnson RA, Wicherm DW. Applied Multivariate Statistical Analysis. 6th ed.; Publiser: Prentice Hill, New Jersey; 2007.

56. Bilgin OC, Emsen E, Davis ME. An application of canonical correlation analysis to relationships between the head and scrotum measurements in awassi fat tailed lambs. J Anim Vet Adv 2003; 2: 343-9.

57. Draper NR, Smith H. Applied regression analysis. 1st ed.; Publiser: John Wiley\&Sons, Inc., New York; 1998.

58. Vainionpaa J, Kervinen R, Prado M, Laurila E, Kari M, Mustonen L, Ahvenainen R. Exploration of storage and process tolerance of different potato cultivars using principal component and canonical correlation analyses. J Food Eng 2000; 44: 47-61.

59. Xian-Li X, Ke-Ming M, Bo-Jie F, Cheng-Jun S, Wen L. Relationships between vegetation and topography in a dry warm river valley SW Chin. Catena 2008; 75: 138-45.

60. Ekanade O, Orimoogunje OOI. Application of canonical correlation for soil-vegetation interrelationship in the cocoa belt of South Western Nigeria. Resour Environ 2012; 2(3): 87-92.

61. Soganci K. Determination of canonic correlation among characteristics of local dry beans (Phaseolus vulgaris L.) genotypes collected from Middle Kızılırmak Valley. PhD, Ahi Evran University, Kırşehir, Turkey; 2017.

62. Sherry A, Henson RK. Conducting and interpreting canonical correlations analysis in personality research: A userfriendly primer. J Pers Assess 2005; 84(1): 37-48.

63. Heenkenda S, Chandrakumara DPS. A canonical analysis on the relationship between financial risk tolerance and household education investment in Sri Lanka. Int J Inno Econ Develop 2015; 1(4): 7-23.

64. Akbas $\mathrm{Y}$, Takma C. Canonical correlation analysis for studying the relationship between egg production traits and body weight, egg weight and age at sexual maturity in layers. Czech J Anim Sci 2005; 50: 163-8. 
65. Centritto M, Loreto F, Massacci A, Pietrini F, Villani MC, Zacchine M. Improved growth and water use efficiency of cherry saplings under reduced light intensity. Ecol Res 2000; 15: 385-92.

66. Uzun S. The quantitative effects of temperature and light environment on the growth, development and yield of tomato (Lycopersicon esculentum Mill.) and aubergine (Solanum melongena L.). PhD, The University of Reading, United Kingdom; 1996.

67. Oner F, Odabas MS, Sezer I, Odabas F. Leaf area prediction for corn (Zea mays L.) cultivars with multiregression analysis. Photosynthetica 2011; 49(4): 637-40.

68. Yerkin D, Temizel KE. The Effects of sodic water applications at different levels on the leaf area and leaf area estimation of bean plants. Black Sea J Agr 2018; 1(3): 70-5.

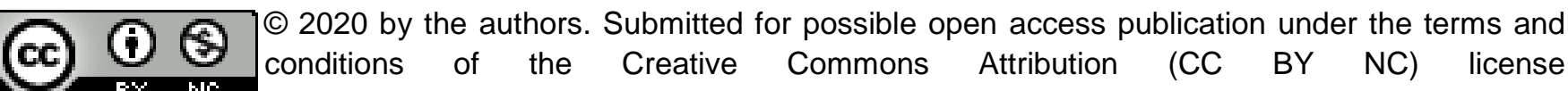
EY NC (https://creativecommons.org/licenses/by-nc/4.0/). 